\title{
CYANIDE-BRIDGED BI- AND TRINUCLEAR HETEROBIMETALLIC Fe(III)—Mn(III) COMPLEXES: SYNTHESIS, CRYSTAL STRUCTURES AND MAGNETIC PROPERTIES
}

\author{
H. Zhang ${ }^{1}$, L. Kong ${ }^{2}$, D. Zhang ${ }^{1}$ \\ ${ }^{1}$ College of Chemical Engineering, Shandong University of Technology, Zibo 255049, P. R. China \\ E-mail: dpzhang73@126.com \\ ${ }^{2}$ Dongchang College, Liaocheng University, Liaocheng 252059, P. R. China
}

Received February, 7, 2015

\begin{abstract}
By employing trans-dicyano or pentacyanometalate as building block and using a bicompartimental Schiff-base based manganese(III) compound as assemble segment, two new cyanidebridged heterometallic $\mathrm{Fe}(\mathrm{III})-\mathrm{Mn}(\mathrm{III})$ complexes $\left\{\left[\mathrm{Mn}(\mathrm{L})\left(\mathrm{H}_{2} \mathrm{O}\right)\right]\left[\mathrm{Febpb}(\mathrm{CN})_{2}\right]\right\} \cdot 2 \mathrm{CH}_{3} \mathrm{OH}$ (1) and $\left\{\left[\mathrm{Mn}(\mathrm{L})\left(\mathrm{H}_{2} \mathrm{O}\right)\right]_{2} \cdot\left[\mathrm{Fe}(\mathrm{CN})_{5} \mathrm{NO}\right]\right\}$ (2) $\left(\mathrm{bpb}^{2-}=1\right.$,2-bis(pyridine-2-carboxamido)benzenete, $\mathrm{L}=\mathrm{N}, \mathrm{N}^{\prime}$-ethylene-bis(3-ethoxysalicylideneiminate) have been synthesized and characterized by elemental analysis, IR spectroscopy and X-ray structure determination. Single X-ray diffraction analysis reveals binuclear FeMn and trinuclear $\mathrm{FeMn}_{2}$ structure, respectively, in which the cyanide precursor acts as mono- or bidentate ligand to connect the Mn(III) Schiffbase unit(s). Furthermore, these two complexes are self-complementary through coordinated aqua ligands from one complex and the free $\mathrm{O}_{4}$ compartments from the neighboring complex, giving dimeric and 1D single chain supramolecular structure. Investigation of the magnetic susceptibility of 1 reveals weak antiferromagnetic coupling between the adjacent $\mathrm{Mn}$ (III) ions. Based on the binuclear FeMn model, best fit of the magnetic susceptibilities of 1 leads to the magnetic coupling constants $J=-1.37 \mathrm{~cm}^{-1}$ and $z J^{\prime}=-0.72 \mathrm{~cm}^{-1}$ (1).
\end{abstract}

DOI: $10.15372 / J S C 20150811$

K e y w o r d s: cyanide-bridged, hydrogen bond, synthesis, crystal structure, magnetic properties.

\section{INTRODUCTION}

During the last 20-30 years, molecular magnetic complexes continue to attract great research interest not only for the purpose of fully elucidating the nature of magnetic coupling, magneto-structural correlation, and some exotic magnetic phenomena but also due to their potential applications in hightech fields [ $1-4]$. Among which, as one of the most important magnetic systems, cyanide-bridged complexes have got much attention since their molecular topological structures and nature of magnetic coupling between neighboring metal ions through the cyanide bridge can be relatively readily controlled and predicted [ 5-9]. Up to now, a large number of cyanide-bridged molecule-based magnetic materials with the structures ranging from discrete polynuclear compounds, one-dimensional chains, two- and three-dimensional networks and interesting magnetic properties, including high- $T_{\mathrm{c}}$, photomagnetic materials, spin crossover ( $\mathrm{SCO}$ ) materials, single-molecule magnets (SMMs), single-chain magnets (SCMs) etc., have been synthesized on the basis of rational selection of magnetic centers and cyanide-containing building blocks [ $10-25]$.

In this process, manganese(III) - salen complexes containing $\mathrm{N}_{2} \mathrm{O}_{2}$ equatorial salen-type ligands play an important role due to their facile preparation and large spin state $(S=2)$, as well as the usually negative magnetic anisotropy of the central Mn(III) ions [26]. Generally, the steric effect of a salen

(C) Zhang H., Kong L., Zhang D., 2015 
Schiff base ligand can be tuned through the peripheral substitution. Our recent reports indicated that Schiff-base manganese(III) compounds containing $\mathrm{N}_{2} \mathrm{O}_{2}$ and $\mathrm{O}_{4}$ coordination sets are good candidates for assembling cyanide-bridged heterometallic magnetic complexes [27, 28 ]. To throw further light on these types of systems, we investigated the reactions of bicompartimental Schiff-base manganese(III) complex $\left[\mathrm{Mn}(\mathrm{L})\left(\mathrm{H}_{2} \mathrm{O}\right)_{2}\right] \mathrm{ClO}_{4},\left(\mathrm{~L}=\mathrm{N}, \mathrm{N}^{\prime}\right.$-ethylene-bis(3-ethoxysalicylideneiminate) (Scheme 1) with trans-dicyanoiron(III) precursor $\mathrm{K}\left[\mathrm{Febpb}(\mathrm{CN})_{2}\right]$ (Scheme 1) $\left(\mathrm{bpb}^{2-}=1\right.$,2-bis(pyridine-2carboxamido)benzenate) or pentacyanometalate $\mathrm{K}_{2}\left[\mathrm{Fe}(\mathrm{CN})_{5} \mathrm{NO}\right]$. Two new cyanide-bridged $\mathrm{Fe}(\mathrm{III})$ $\mathrm{Mn}(\mathrm{III})$ complexes belonging to discrete bi- and trinuclear structure, $\left\{\left[\mathrm{Mn}(\mathrm{L})\left(\mathrm{H}_{2} \mathrm{O}\right)\right]\left[\mathrm{Febpb}(\mathrm{CN})_{2}\right]\right\}$. $\cdot 2 \mathrm{CH}_{3} \mathrm{OH}(1)$ and $\left\{\left[\mathrm{Mn}(\mathrm{L})\left(\mathrm{H}_{2} \mathrm{O}\right)\right]_{2}\left[\mathrm{Fe}(\mathrm{CN})_{5} \mathrm{NO}\right]\right\}$ (2), which can be further constructed into dimeric and 1D single chain supramolecular structures by intermolecular hydrogen bond interactions, including their synthesis, crystal structures and magnetic properties, will be described in this paper.
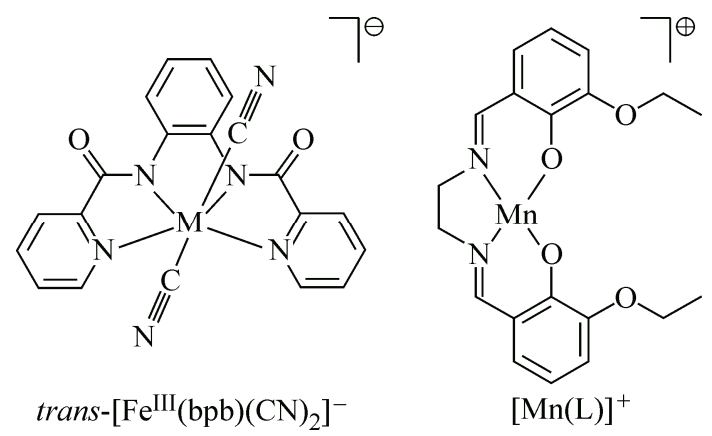

Scheme 1

\section{EXPERIMENTAL SECTION}

General procedures and materials. All the reactions were carried out in air, and all chemicals and solvents were reagent grade without further purification. $\left[\mathrm{Mn}(\mathrm{L})\left(\mathrm{H}_{2} \mathrm{O}\right)_{2}\right] \mathrm{ClO}_{4}$ and $\mathrm{K}\left[\mathrm{Febpb}(\mathrm{CN})_{2}\right]$ were prepared according to the previous reports [29, 30 ].

Caution! Perchlorate salts of metal complexes with organic ligands are potentially explosive and should be handled in small quantities with care.

The preparation of complex $1 . \mathrm{K}\left[\mathrm{Febpb}(\mathrm{CN})_{2}\right](0.1 \mathrm{mmol}, 46.5 \mathrm{mg})$ dissolved in distilled water $(10 \mathrm{ml})$ was added to a methanol solution $(10 \mathrm{ml})$ of $\left[\mathrm{Mn}(\mathrm{L})\left(\mathrm{H}_{2} \mathrm{O}\right)_{2}\right] \mathrm{ClO}_{4}(0.1 \mathrm{mmol}, 58.8 \mathrm{mg})$. The mixture was stirred for several minutes at room temperature and filtered to remove any insoluble material, and the filtrate was allowed to evaporate slowly without disturbance. The dark-brown crystals suitable for X-ray diffraction were collected by filtration after two weeks, washed with cold methanol and dried in air. Yield $49 \mathrm{mg}, 54 \%$. Anal. Calcd. for $\mathrm{C}_{42} \mathrm{H}_{44} \mathrm{FeMnN}_{8} \mathrm{O}_{9}(\%)$ : C 55.09, H 4.84, N 12.24. Found (\%): C 55.01, H 4.78, N 12.48. Main IR bands $\left(\mathrm{cm}^{-1}\right)$ : 2155, $2120(\mathrm{~s}, \mathrm{vC} \equiv \mathrm{N}), 1615-1635$ (vs, $v \mathrm{C}=\mathrm{N})$.

The preparation of complex 2. A solution containing $\mathrm{K}_{2}\left[\mathrm{Fe}(\mathrm{CN})_{5} \mathrm{NO}\right](0.1 \mathrm{mmol}, 29.4 \mathrm{mg})$ dissolved in $5 \mathrm{ml}$ distilled water was laid in the bottom of a tube, upon which a mixture of water and methanol $(5 \mathrm{ml}, v / v, 1: 1)$ was carefully layered. Then, a solution of $\left[\mathrm{Mn}(\mathrm{L})\left(\mathrm{H}_{2} \mathrm{O}\right)_{2}\right] \mathrm{ClO}_{4}(0.2 \mathrm{mmol}$, $117 \mathrm{mg}$ ) in $5 \mathrm{ml}$ of $\mathrm{CH}_{3} \mathrm{OH}$ was carefully added at the top of the solvent layer. Single crystals suitable for X-ray diffraction were obtained about one week later, and were collected by filtration and dried in air. Yield $53 \mathrm{mg}, 50 \%$. Anal. Calcd. for $\mathrm{C}_{45} \mathrm{H}_{48} \mathrm{FeMn}_{2} \mathrm{~N}_{10} \mathrm{O}_{11}$ (\%): $\mathrm{C} 50.48, \mathrm{H}$ 4.52, N 13.08. Found (\%): C 50.14, H 4.33, N 13.46. Main IR bands $\left(\mathrm{cm}^{-1}\right): 2150,2125(\mathrm{~s}, \mathrm{vC} \equiv \mathrm{N}), 1925\left(\mathrm{~s}, v_{\mathrm{NO}}\right), 1615-$ $1635(\mathrm{vs}, \mathrm{vC}=\mathrm{N})$.

X-ray data collection and structure refinement. Single crystals of complexes $\mathbf{1}$ and $\mathbf{2}$ for X-ray diffraction analyses with suitable dimensions were mounted on a glass rod and the crystal data were collected on a Bruker SMART CCD diffractometer with a $\operatorname{Mo} K_{\alpha}$ sealed tube $(\lambda=0.71073 \AA)$ at $293 \mathrm{~K}$, using $\omega$ scan mode. The structures were solved by direct method and expanded using Fourier difference techniques with the SHELXTL-97 program package [31 ]. The non-hydrogen atoms were refined anisotropically, while hydrogen atoms were introduced as fixed contributors. All the non- 
Crystallographic data for complexes $\mathbf{1}$ and $\mathbf{2}$

\begin{tabular}{l|c|c}
\hline \multicolumn{1}{c|}{ Parameter } & $\mathbf{1}$ (No. 1024299) & $\mathbf{2}$ (No. 1024300) \\
\hline Chemical formula & $\mathrm{C}_{42} \mathrm{H}_{44} \mathrm{FeMnN}_{8} \mathrm{O}_{9}$ & $\mathrm{C}_{45} \mathrm{H}_{48} \mathrm{FeMn}_{2} \mathrm{~N}_{10} \mathrm{O}_{11}$ \\
$F w$ & 915.64 & 1070.66 \\
Temperature, $\mathrm{K}$ & 293 & 293 \\
Size, mm & $0.11 \times 0.13 \times 0.15$ & $0.15 \times 0.19 \times 0.21$ \\
Color & Dark-brown & Dark-brown \\
Density, g/cm ${ }^{3}$ & 1.351 & 1.498 \\
Crystal system & Monoclinic & Monoclinic \\
Space group & $P 2(1) / n$ & $P 2(1) / n$ \\
$a, b, c, \AA ; \beta$, deg. & $14.4616(14), 12.7434(12)$, & $13.2894(12), 13.2449(11)$, \\
& $24.430(2) ; 91.316(2)$ & $14.9283(13) ; 115.4190(10)$ \\
$V, \AA^{3}$ & $4501.0(7)$ & $2373.3(4)$ \\
$Z$ & 4 & 2 \\
Completeness, \% & 99.0 & 99.9 \\
$F(000)$ & 1900 & 1104 \\
Reflections (observed) & $7835(5879)$ & $4179(3804)$ \\
Parameters & 556 & 315 \\
Absorption coefficient & 0.664 & 0.896 \\
$\theta$, deg. & 1.65 to 25.00 & 2.16 to 25.01 \\
GOOF & 1.047 & 1.112 \\
$R_{1}[I>2 \sigma(I)]$ & 0.0780 & 0.0323 \\
$w R_{2}$ (all data) & 0.2559 & 0.0820 \\
Largest difference in peak and hole, e/ $\AA^{3}$ & 1.189 and -1.631 & 0.303 and -0.363 \\
& &
\end{tabular}

hydrogen atoms were refined with anisotropic displacement coefficients. Hydrogen atoms were assigned isotropic displacement parameters $U(\mathrm{H})=1.2 U(\mathrm{C})$ or $1.5 U(\mathrm{C})$ and their coordinates were allowed to ride on respective carbons using SHELXL97, except some H atoms of the solvent molecules, which were refined isotropically with fixed $U$ values. The DFIX command was used to rationalize the bond parameter. CIF files containing complete information on the structure were deposited under CCDC deposition number 1024299 and 1024300, and are freely available upon request from the following web site: www.ccdc.cam.ac.uk/data request/cif. Details of the crystal parameters, data collection, and refinement are summarized in Table 1 .

\section{RESULTS AND DISCUSSION}

Synthesis and general characterization. Manganese(III) - salen types of Schiff-base compounds ( salen $=\mathrm{N}, \mathrm{N}$-ethylene-bissalicylideneiminate) have been widely used to prepare cyanide-bridged magnetic complexes. The main reason is their facile preparation and large spin state $(S=2)$, as well as the predominantly negative magnetic anisotropy of the central $\mathrm{Mn}(\mathrm{III})$ ions. [26]. The reactions of bicompartimental salen type of manganese Schiff-base ligand compound $\left[\mathrm{Mn}(\mathrm{L})\left(\mathrm{H}_{2} \mathrm{O}\right)_{2}\right] \mathrm{ClO}_{4}$ with $\mathrm{K}\left[\mathrm{Febpb}(\mathrm{CN})_{2}\right]$ or $\mathrm{K}_{2}\left[\mathrm{Fe}(\mathrm{CN})_{5} \mathrm{NO}\right]$ result in neutral bi- or trinuclear cyanide-bridged $\mathrm{Fe}(\mathrm{III})-\mathrm{Mn}(\mathrm{III})$ complexes, whose structures are different from those obtained from the reactions with $\mathrm{K}\left[\mathrm{Febpb}(\mathrm{CN})_{2}\right]$ or $\mathrm{K}_{2}\left[\mathrm{Fe}(\mathrm{CN})_{5}(1-\mathrm{MeIm})\right]$, demonstrating that the size of the substituent group on the Schiff-base ligand has obvious influence on the structure of the target complexes [27,28]. The two cyanidebridged heterometallic complexes have been characterized by IR spectroscopy. In the IR spectra of complexes $\mathbf{1}$ and 2, two sharp peaks due to the cyanide-stretching vibration were observed at about $2120 \mathrm{~cm}^{-1}$ and $2155 \mathrm{~cm}^{-1}$, respectively, indicating the presence of bridging and non-bridging cyanide groups in these complexes. For complex 2, an additional absorption band due to $v_{\text {NO }}$ (nitrosyl) was observed at $1925 \mathrm{~cm}^{-1}$, confirming the presence of nitroprusside in the compound. 
Selected bond lengths $(\AA)$ and angles (deg.) for complexes $\mathbf{1}$ and $\mathbf{2}$

\begin{tabular}{l|l|l|l|l|l}
\hline \multicolumn{5}{c|}{1} & \multicolumn{2}{c}{2} \\
\hline $\mathrm{Mn} 1-\mathrm{N} 2$ & $2.294(5)$ & $\mathrm{C}(2)-\mathrm{N}(2)-\mathrm{Mn}(1)$ & $161.2(4)$ & $\mathrm{Mn}(1)-\mathrm{O}(1)$ & $1.8819(15)$ \\
$\mathrm{Mn} 1-\mathrm{N} 7$ & $1.970(5)$ & $\mathrm{N}(1)-\mathrm{C}(1)-\mathrm{Fe}(1)$ & $176.8(6)$ & $\mathrm{Mn}(1)-\mathrm{O}(3)$ & $1.8752(14)$ \\
$\mathrm{Mn} 1-\mathrm{N} 8$ & $1.975(5)$ & $\mathrm{N}(2)-\mathrm{C}(2)-\mathrm{Fe}(1)$ & $173.6(4)$ & $\mathrm{Mn}(1)-\mathrm{O}(5)$ & $2.2739(15)$ \\
$\mathrm{Mn} 1-\mathrm{O} 3$ & $1.871(4)$ & $\mathrm{N}(2)-\mathrm{Mn}(1)-\mathrm{O}(7)$ & $171.16(16)$ & $\mathrm{Mn}(1)-\mathrm{N}(1)$ & $2.377(2)$ \\
$\mathrm{Mn} 1-\mathrm{O} 4$ & $1.876(4)$ & & $\mathrm{Mn}(1)-\mathrm{N}(5)$ & $1.9796(18)$ \\
$\mathrm{Mn} 1-\mathrm{O} 7$ & $2.302(4)$ & & $\mathrm{Mn}(1)-\mathrm{N}(6)$ & $1.9860(18)$ \\
$\mathrm{Fe}(1)-\mathrm{C}(1)$ & $1.949(6)$ & \multicolumn{2}{|c}{$\mathbf{2}$} & $\mathrm{Fe}(1)-\mathrm{C}(1)$ & $1.940(2)$ \\
\cline { 3 - 4 } $\mathrm{Fe}(1)-\mathrm{C}(2)$ & $1.969(5)$ & $\mathrm{C}(1)-\mathrm{N}(1)-\mathrm{Mn}(1)$ & $145.52(18)$ & $\mathrm{Fe}(1)-\mathrm{C}(2)$ & $1.942(2)$ \\
$\mathrm{Fe}(1)-\mathrm{N}(3)$ & $1.888(4)$ & $\mathrm{N}(1)-\mathrm{C}(1)-\mathrm{Fe}(1)$ & $174.0(2)$ & $\mathrm{Fe}(1)-\mathrm{N}(4)$ & $1.809(2)$ \\
$\mathrm{Fe}(1)-\mathrm{N}(4)$ & $1.888(4)$ & $\mathrm{N}(2)-\mathrm{C}(2)-\mathrm{Fe}(1)$ & $176.1(2)$ & $\mathrm{Fe}(1)-\mathrm{C}(1) \# 1$ & $1.940(2)$ \\
$\mathrm{Fe}(1)-\mathrm{N}(5)$ & $1.994(4)$ & $\mathrm{O}(5)-\mathrm{Mn}(1)-\mathrm{N}(1)$ & $169.23(6)$ & $\mathrm{Fe}(1)-\mathrm{C}(2) \# 1$ & $1.942(2)$ \\
$\mathrm{Fe}(1)-\mathrm{N}(6)$ & $1.997(4)$ & \multicolumn{2}{|l}{} & &
\end{tabular}

Symmetry transformations used to generate equivalent atoms for complex 2: $\# 1$ : $-x+1$, $-y+1,-z+1$.

Crystal structures of complexes 1 and 2. Important structural parameters for complexes $\mathbf{1}$ and $\mathbf{2}$ are collected in Table 2. The neutral binuclear structure of complex $\mathbf{1}$ and its dimeric supramolecular structure are shown in Fig. 1. For complex 2, the trinuclear molecular structure and 1D supramolecular structure formed by the intermolecular hydrogen bond interactions are given in Fig. 2.

As can be found in Table 2, these two complexes crystallize in a monoclinic space group $P 2(1) / n$ and contain four and two independent units in the unit cell, respectively. The trans-dicyanide building block in complex $\mathbf{1}$ acts as a monodentate ligand through one of its two cyanide groups towards the central $\mathrm{Mn}(\mathrm{III})$ ion, while two $\left[\mathrm{Mn}(\mathrm{L})\left(\mathrm{H}_{2} \mathrm{O}\right)\right]^{+}$units are connected by two cyanide groups in a trans position of the pentacyanometalate, acting as bidentate ligand in complex $\mathbf{2}$, therefore generating neutral binuclear FeMn and trinuclear FeMn $\mathrm{H}_{2}$ entities, respectively. In complex 1, the Fe(III) ion is coordinated by four $\mathrm{N}$ atoms of the cyanide-containing precursor and two $\mathrm{C}$ atoms of cyanide groups in trans position, thus forming a slightly distorted octahedral geometry (Table 2). The bond angles of $\mathrm{Fe}-$ $\mathrm{C} \equiv \mathrm{N}\left(176.8(6)^{\circ}\right.$ and $\left.173.6(4)^{\circ}\right)$ clearly indicate that the three atoms are in a linear arrangement.

The coordination sphere around the $\mathrm{Mn}^{3+}$ ion in both complexes is a distorted octahedral, in which four equatorial positions are occupied by a $\mathrm{N}_{2} \mathrm{O}_{2}$ unit from the Schiff-base ligand, and the other
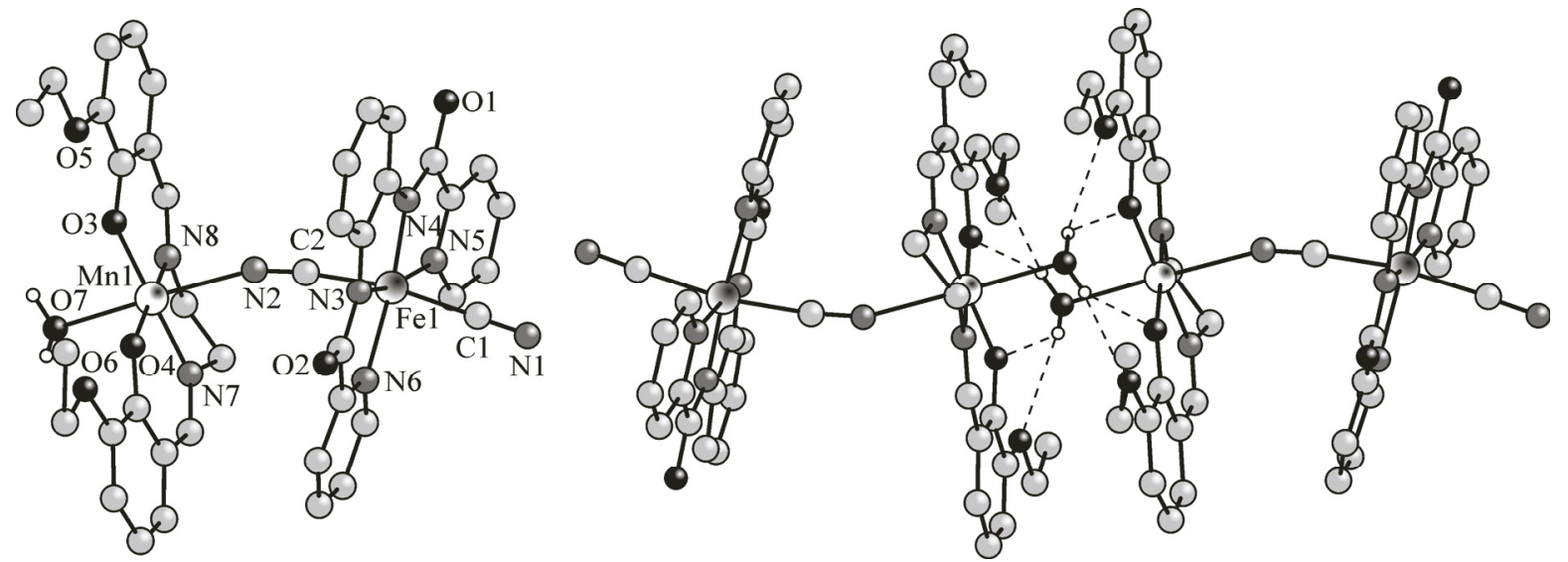

Fig. 1. The binuclear and the dimer structure of complex 1. The solvent molecules and all the H atoms except those forming hydrogen bonds are omitted for clarity 

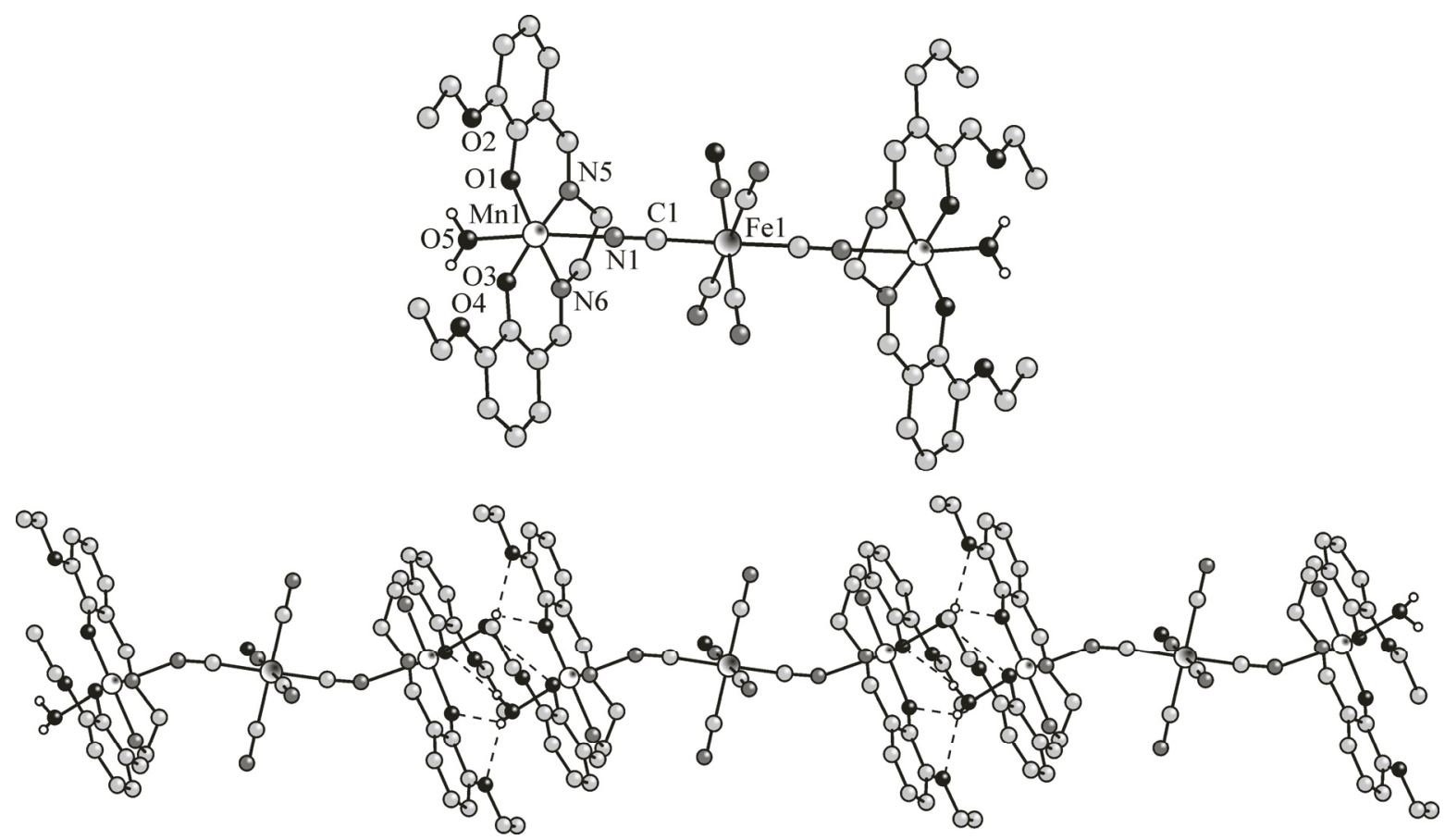

Fig. 2. The trinuclear entity (top) and the 1D single chain structure (bottom) constructed by intermolecular hydrogen bonding interactions for complex 2. All the $\mathrm{H}$ atoms except those forming hydrogen bonds are omitted for clarity

two axial ones come from the $\mathrm{N}$ atoms of the bridging cyanide group and the $\mathrm{O}$ atom of the coordinated water molecule. As shown in Table 2, the distances between the Mn atom and the $\mathrm{N}, \mathrm{O}$ atoms of the Schiff-base ligand within the range 1.871(4)-1.9860(18) $\AA$ are obviously shorter than the $\mathrm{Mn}-\mathrm{N}_{\text {cyanide }}$ and $\mathrm{Mn}-\mathrm{O}_{\text {water }}$ bond lengths with the average values $2.34 \AA$ and $2.29 \AA$, respectively, which gives further information about the elongation of the octahedron surrounding the $\mathrm{Mn}^{3+}$ ion, accounting for the well known Jahn-Teller effect along the $\mathrm{N}_{\text {cyanide }}-\mathrm{Mn}-\mathrm{O}_{\text {water }}$ axial direction in a typical way. The $\mathrm{C}_{\text {cyanide }} \equiv \mathrm{N}_{\text {cyanide }}-\mathrm{Mn}$ angles are strongly bent and deviate obviously from a linear configuration with the values of $161.2(4)^{\circ}$ and $145.52(18)^{\circ}$, respectively. It is worth noting that the cyanide-bridged discrete moieties are self-complementary through the intermolecular $\mathrm{O}-\mathrm{H} \ldots \mathrm{O}$ hydrogen bond interactions between the coordinated aqua ligand from one complex and the free $\mathrm{O}_{4} \mathrm{com}-$ partment from the neighboring complex, forming a supramolecular dimer and one-dimensional chain structures for complexes 1 and $\mathbf{2}$, respectively (Figs. 1 and 2). The intramolecular $\mathrm{Fe}^{\mathrm{III}}-\mathrm{Mn}^{\mathrm{III}}$ separation through bridging cyanide group is $5.299 \AA$ in complex $\mathbf{1}$, while that in complex $\mathbf{2}$ is $10.326 \AA$ due to the long diamagnetic $\left[\mathrm{Fe}(\mathrm{CN})_{5} \mathrm{NO}\right]^{2-}$ bridge.

Magnetic properties of complex 1. The temperature dependence of $\chi_{m} T$ for complex 1 measured

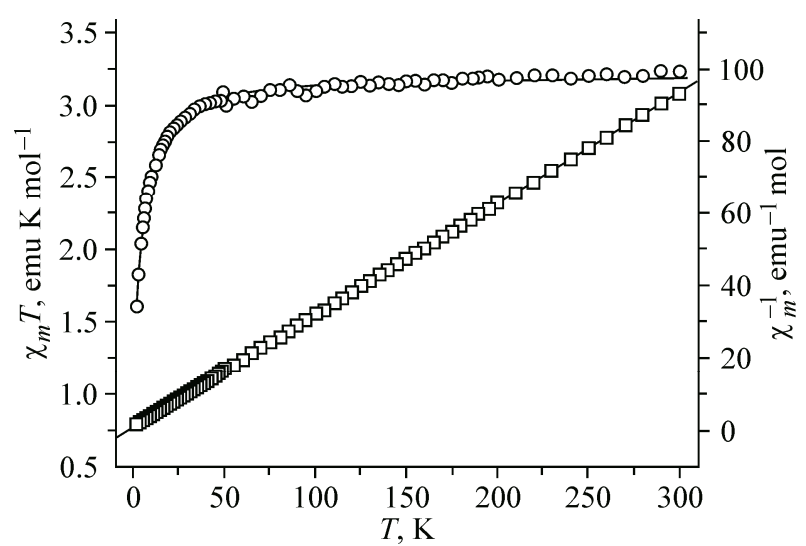
in the range of $2-300 \mathrm{~K}$ is shown in Fig. 3. The $\chi_{m} T$ value at $300 \mathrm{~K}$ is $3.23 \mathrm{emu} \cdot \mathrm{K} \cdot \mathrm{mol}^{-1}$, which is basically consistent with the spin only value of $3.38 \mathrm{emu} \cdot \mathrm{K} \cdot \mathrm{mol}^{-1}$ for one high spin $\mathrm{Mn}(\mathrm{III})$ and one low spin Fe(III). During the process of lowering the temperature from $300 \mathrm{~K}$ to about $50 \mathrm{~K}$,

Fig. 3. Temperature dependences of $\chi_{m} T-T$ (the solid line represents the best fit based on the parameters discussed in the text) for complex 1. Inset: Temperature dependence $\chi_{m}{ }^{-1}-T$ (the solid line was calculated from the Curie-Weiss law) 
the $\chi_{m} T$ value decreases slowly to $3.01 \mathrm{emu} \cdot \mathrm{K} \cdot \mathrm{mol}^{-1}$. After that, the $\chi_{m} T$ value starts to decrease rapidly to the minimum of $1.61 \mathrm{emu} \cdot \mathrm{K} \cdot \mathrm{mol}^{-1}$ at $2 \mathrm{~K}$. The magnetic susceptibility of 1 conforms well to Curie-Weiss law in the range of $2-300 \mathrm{~K}$, and gives negative Weiss constant $\theta=-3.31 \mathrm{~K}$ and Curie constant $C=3.24 \mathrm{emu} \cdot \mathrm{K} \cdot \mathrm{mol}^{-1}$. The negative Weiss constant as well as the change tendency of the $\chi_{m} T-T$ give information that there exist overall antiferromagnetic interactions between the $\mathrm{Fe}(\mathrm{III})$ and $\mathrm{Mn}(\mathrm{III})$ ions bridged by a cyanide group.

The cryomagnetic behaviour of complex 1 can attributed to the following factors: intramolecular interaction mediated by the cyanide bridge, zero field splitting of the $\mathrm{Mn}$ (III) ion and/or the intermolecular supramolecular interactions. Previous works have shown that the magnetic anisotropy and intermolecular interactions $\left(z J^{\prime}\right)$ might produce similar effects on magnetic properties at very low temperature $[32,33]$, and thus it is not reasonable to estimate them independently. To avoid overparametrization, the contribution brought by magnetic anisotropy was neglected, while taking account of the intermolecular interactions $\left(z J^{\prime}\right)$ in the frame of the mean-field approximation. On the basis of the binuclear $\mathrm{Fe}^{\mathrm{III}}-\mathrm{Mn}^{\mathrm{III}}(S=1 / 2$ and 2$)$ model, the magnetic susceptibility of complex 1 can be fitted by the expression below derived from the isotropic exchange spin Hamiltonian $\hat{H}=-2 J \hat{\mathrm{S}}_{\mathrm{Fe}} \hat{\mathrm{S}}_{\mathrm{Mn}}$ :

$$
\begin{gathered}
\chi_{d}=\frac{N g^{2} \beta^{2}}{2 k T} \frac{35 \exp (2 J / k T)+10 \exp (-3 J / k T)}{6 \exp (2 J / k T)+4 \exp (-3 J / k T)}, \\
\chi_{m}=\frac{\chi_{d}}{1-\chi_{d}\left(2 z J^{\prime} / N g^{2} \beta^{2}\right)} .
\end{gathered}
$$

The best-fit parameters obtained are $J=-1.37 \mathrm{~cm}^{-1}, g=2.01, z J^{\prime}=-0.72 \mathrm{~cm}^{-1}, R=2.39 \times 10^{-5}$ ( $R$ is the agreement factor defined as $\left.\sum\left(\chi_{\text {obsd }} T-\chi_{\text {cald }} T\right)^{2} / \sum\left(\chi_{\mathrm{obsd}} T\right)^{2}\right)$. These fitting values are comparable with those for the reported cyanide-bridged binuclear Fe-Mn complex [34, 28, 35$]$.

\section{CONCLUSIONS}

Heterobimetallic bi- and trinuclear cyanide-bridged complexes have been designed and synthesized based on bicompartimental Schiff Base manganese(III) segment using trans-dicyanidecontaining precursor $\mathrm{K}\left[\mathrm{Fe}(\mathrm{bpb})(\mathrm{CN})_{2}\right]$ or nitroprusside $\mathrm{K}_{2}\left[\mathrm{Fe}(\mathrm{CN})_{5} \mathrm{NO}\right]$ as building block. Investigation of the magnetic properties of the complex reveals overall antiferromagnetic interaction between the cyanide-bridged $\mathrm{Fe}-\mathrm{Mn}$ metal centers. These results and those reported recently by our group $[27,28]$ indicate that the bicompartimental Schiff-base manganese(III) compounds are good candidates for assembling cyanide-bridged heterometallic complexes with various structure types.

This work was supported by the Natural Science Foundation of China (21171107), the Natural Science Foundation of Shandong Province (ZR2011BM008) and the Science and Technology Project of High Education, Shandong Province (No. J11LB09).

\section{REFERENCES}

1. Cornia A., Mannini M., Sainctavit P. et al. // Chem. Soc. Rev. - 2011. - 40. - P. 3076.

2. Dechambenoit P., Long J.R. // Chem. Soc. Rev. - 2011. - 40. - P. 3249.

3. Sanvito S. // Chem. Soc. Rev. - 2011. - 40. - P. 3336.

4. Sorace L., Benelli C., Gatteschi C.D. // Chem. Soc. Rev. - 2011. - 40. - P. 3092.

5. Dunbar K.R., Heintz R.A. // Prog. Inorg. Chem. - 1997. - 45. - P. 283.

6. Verdaguer M., Bleuzen A., Marvaud V. et al. // Coord. Chem. Rev. - 1999. - 190-192. - P. 1023.

7. Ohba M., Okawa H. // Coord. Chem. Rev. - 2000. - 198, N 1. - P. 313.

8. Cernák J., Orendác M., Potocnák I. et al. // Coord. Chem. Rev. - 2002. - 224, N 1-2. - P. 51.

9. Shatruk M., Avendano C., Dunbar K.R. // Prog. Inorg. Chem. - 2009. - 56. - P. 155.

10. Sato O., Iyoda T., Fujishima A. et al. // Science. - 1996. - 271. - P. 49.

11. Sato O., Iyoda T., Fujishima A. et al. // Science. - 1996. - 272. - P. 704.

12. Bleuzen A., Marvaud V., Mathonière C. et al. // Inorg. Chem. - 2009. - 48, N 8. - P. 3453.

13. Martínez V., Boldog I., Gaspar A.B. et al. // Chem. Mater. - 2010. - 22, N 14. - P. 4271.

14. Bartual-Murgui C., Salmon L., Akou A. et al. // Chem. Eur. J. - 2012. - 18, N 2. - P. 507. 
15. Jeon I.R., Calancea S., Panja A. et al. // Chem. Sci. - 2013. - 4. - P. 2463.

16. Shiga T., Newton G.N., Mathieson J.S. et al. // Dalton Trans. - 2010. - 39, N 20. - P. 4730.

17. Yao M.X., Zheng Q., Cai X.M. et al. // Inorg. Chem. - 2012. - 51, N 4. - P. 2140.

18. Liu C.M., Xiong G.R., Zhang D.Q. et al. // J. Am. Chem. Soc. - 2010. - 132, N 12. - P. 4044.

19. Gruselle M., Train C., Boubekeur K. et al. // Coord. Chem. Rev. - 2006. - 250, N 19-20. - P. 2491.

20. Zhang D.P., Bian Y.Z., Qin J. et al. // Dalton Trans. - 2014. - 43, N 3. - P. 945.

21. Freedman D.E., Jenkins D.M., Iavarone A.T. et al. // J. Am. Chem. Soc. - 2008. - 130, N 10. - P. 2884.

22. Goodwin A.L., Kennedy B.J., Kepert C. // J. Am. Chem. Soc. - 2009. - 131, N 18. - P. 6334.

23. Ni Z.H., Kou H.Z., Zhang L.F. et al. // Angew. Chem., Int. Ed. - 2005. - 44, N 47. - P. 7742.

24. Toma L.M., Lescouëzec R., Pasan J. et al. // J. Am. Chem. Soc. - 2006. - 128, N 14. - P. 4842.

25. Zhang D.P., Zhang L.F., Chen Y.T. et al. // Chem. Commun. - 2010. - 46, N 20. - P. 3550.

26. Miyasaka H., Saitoh A., Abe S. // Coord. Chem. Rev. - 2007. - 251, N 21-24. - P. 2622.

27. Zhang D.P., Wang H.L., Chen Y.T. et al. // Inorg. Chem. - 48, N 23. - P. 11215.

28. Zhang D.P., Zhang L.F., Chen X. et al. // Inorg. Chim. Acta. - 2011. - 377, N 1. - P. 165.

29. Miyasaka H., Matsumoto N., Okawa H. et al. // J. Am. Chem. Soc. - 118, N 1. - P. 981.

30. Ray M., Mukherjee R., Richardson J.F. et al. // J. Chem. Soc., Dalton Trans. - 1993. - N 16. - P. 2451.

31. Sheldrick G.M. SHELX-97. - Germany: Universität Göttingen, 1997.

32. Myers B.E., Berger L., Friedberg S. // J. Appl. Phys. - 1969. - 40, N 3. - P. 1149.

33. O'Connor C.J. // Prog. Inorg. Chem. - 1982. - 29. - P. 203.

34. Nastase S., Maxim C., Andruh M. et al. // Dalton Trans. - 2011. - 40, N 18. - P. 4898.

35. Zhang D.P., Wang H.L., Tian L.J. et al. // Cryst. Growth Des. - 2009. - 9, N 9. - P. 3989. 